\title{
PENGARUH MODEL COLLABORATIVE LEARNING TERHADAP KEMAMPUAN PEMECAHAN MASALAH MATEMATIKA DAN SIKAP SOSIAL SISWA KELAS V SD JARAKAN SEWON BANTUL
}

\author{
Eni Purwaaktari \\ SD Timbulharjo \\ Email: eni_purwa@yahoo.co.id
}

\begin{abstract}
Abstrak
Penelitian ini bertujuan untuk mendeskripsikan pengaruh model collaborative learning terhadap kemampuan pemecahan masalah Matematika dan sikap sosial siswa kelas V SD Jarakan. Penelitian ini merupakan penelitian quasi experiment dengan desain randomized pretest-postest control group design. Populasi dalam penelitian ini adalah seluruh kelas V SD Jarakan pada tahun pelajaran 2014/2015 yang terdiri dari empat kelas yaitu kelas 5a, 5b, 5c, dan 5d. Sampel sejumlah tiga kelas (dua kelas sebagai kelompok eksperimen dan satu kelas sebagai kelompok kontrol) ditentukan melalui pengundian. Data dikumpulkan menggunakan tes dan angket. Validitas instrumen tes dan angket diperoleh dari expert judgement sedangkan estimasi reliabilitasnya diperoleh dengan menggunakan rumus Alpha Cronbach. Data dianalisis menggunakan uji t dan uji ${ }^{2}$ Hotelling's dengan taraf signifikansi 5\%. Hasil penelitian menunjukkan bahwa: (1) terdapat pengaruh positif dan signifikan penggunaan model collaborative learning terhadap kemampuan pemecahan masalah Matematika siswa, (2) terdapat pengaruh positif dan signifikan penggunaan model collaborative learning terhadap sikap sosial siswa, dan (3) terdapat pengaruh positif dan signifikan penggunaan model collaborative learning terhadap kemampuan pemecahan masalah Matematika dan sikap sosial siswa yang diteliti.
\end{abstract}

Kata kunci: collaborative learning, kemampuan pemecahan masalah Matematika, sikap sosial

\section{EFFECT OF COLLABORATIVE LEARNING MODEL ON THE MATHEMATICAL PROBLEM SOLVING ABILITY AND SOCIAL ATTITUDES OF THE FIFTH GRADE STUDENTS OF JARAKAN ELEMENTARY SCHOOL}

\begin{abstract}
The purpose of this study is to describe the effect of collaborative learning model on the mathematical problem solving ability and social attitudes of the fifth grade students of Jarakan Elementary School. This study is quasi experimental with randomized pretest-posttest control group design. The population was all fifth grade classes of Jarakan Elementary School in 2014/2015 which consisted of four classes: $5 a, 5 b, 5 c$, and $5 d$ classes. A sample of three classes was established by lottery where two classes were as the experimental groups and one class as the control group. The data were collected using a test and a questionnaire. The validity of the test and questionnaire was obtained from experts' judgement while the reliability estimate was obtained using the Alpha Cronbach formula. The data were analyzed using the independent sample t-test and ${ }^{2}$ Hotelling's with the significance level of 5\%. The results show that: (1) there is a positive and significant effect of the implementation of collaborative learning model on the students' mathematical problem solving ability, (2) there is a positive and significant effect of the implementation of collaborative learning model on the students' social attitudes, and (3) there is a positive and significant effect of the implementation of collaborative learning model on the students' mathematical problem solving ability and social attitudes.
\end{abstract}

Keywords: collaborative learning, mathematical problem solving ability, social attitudes 


\section{PENDAHULUAN}

Matematika merupakan ilmu yang memajukan daya pikir manusia dan mendasari perkembangan ilmu pengetahuan dan teknologi. Dengan mempelajari Matematika maka kemampuan berpikir logis, analitis, sistematis, kritis, dan kreatif dapat berkembang. Kemampuan-kemampuan ini penting karena membantu manusia untuk belajar mengorganisasi, menganalisis, dan mensistesis informasi sehingga mempermudah manusia dalam menyelesaikan masalah-masalah dalam kehidupannya. Manusia juga dapat menciptakan berbagai teknologi informasi dan komunikasi modern dewasa ini berkat perkembangan ilmu Matematika. Jadi, penguasaan Matematika sejak dini penting untuk penguasaan dan penciptaan teknologi di masa depan serta sebagai bekal dalam menghadapi tantangan perkembangan zaman.

Manusia membutuhkan Matematika karena Matematika untuk hidup, Matematika sebagai warisan budaya, Matematika untuk tempat kerja, dan Matematika untuk komunitas ilmiah dan teknik (NCTM, 2000:4). Kebutuhan Matematika untuk hidup didasarkan pada pentingnya penggunaan Matematika dalam kehidupan sehari-hari. Matematika sebagai warisan budaya karena Matematika merupakan prestasi budaya dan intelektual terbesar manusia yang harus diapresiasi dan dikembangkan. Kebutuhan Matematika untuk tempat kerja didasarkan pada pentingnya pemikiran matematis dan pemecahan masalah di semua tempat kerja. Kebutuhan Matematika untuk komunitas ilmiah dan teknik didasarkan pada banyaknya peserta didik yang menempuh jalur pendidikan untuk mempersiapkan diri mereka bekerja sebagai Matematikawan, ahli statistik, insinyur, dan ilmuwan. Dengan demikian, ilmu Matematika sangat penting untuk dipelajari karena dibutuhkan dalam kehidupan sehari-hari dan untuk meraih kesuksesan hidup di masa depan.
Mengingat pentingnya Matematika, maka guru sebagai praktisi pendidikan yang memegang peranan penting dalam usaha memajukan pendidikan di Indonesia hendaknya dapat menciptakan proses pembelajaran Matematika yang efektif. Prinsip-prinsip pengajaran Matematika yang efektif menurut NCTM (2000:16) adalah: 1) Effective mathematics teaching requires understanding what students know and need to learn and then challenging and supporting them to learn it well; 2) Effective teaching requires knowing and understanding mathematics, students as learners, and pedagogical strategies; 3) Effective teaching requires a challenging and supportive classroom learning environment; dan 4) Effective teaching requires continually seeking improvement. Dengan demikian, pembelajaran Matematika menjadi efektif apabila guru dapat menyajikan pembelajaran sesuai dengan keinginan dan kebutuhan belajar siswa sehingga siswa dapat terlibat aktif dan termotivasi dalam mempelajarinya; adanya pemahaman tentang Matematika, siswa itu sendiri, dan strategi pendidikan; tersedianya lingkungan belajar yang menantang dan mendorong siswa untuk belajar; dan adanya perbaikan kualitas pembelajaran yang berkelanjutan.

Pemecahan masalah merupakan salah satu topik penting dalam mempelajari Matematika karena belajar memecahkan masalah merupakan prinsip dasar dalam mempelajari Matematika. Reys, et al. (2012:89) menyatakan bahwa: "Problem solving is the foundation of all mathematic activity. As such, problem solving should play a prominent role in the elementary school mathematics curriculum." Jadi, pemecahan masalah merupakan dasar dari semua aktivitas Matematika. Oleh sebab itu, pemecahan masalah harus memegang peranan penting dalam kurikulum Matematika sekolah dasar.

Pemecahan masalah Matematika penting untuk dipelajari siswa karena membantu mereka dalam mengembangkan 
keterampilan, melakukan praktek, bekerja lebih aktif, dan berpikir secara sistematis. Hal ini sesuai dengan pendapat Bennett, Burton, \& Nelson (2012:1) bahwa:

Working on this problem offers good practice in addition skills. But the important mathematical goal of this problemhelping students to think systematically about possibilities and to organize and record their thinking - need not wait until students can add fluently.

Dengan demikian, kegiatan pemecahan suatu masalah Matematika memberi kesempatan kepada siswa untuk aktif mengorganisasikan pemikirannya sehingga tidak menjadi pembelajar yang sangat bergantung kepada penjelasan guru.

Ketika siswa bekerja keras untuk memecahkan masalah yang sulit, maka mereka akan memperoleh pengalaman yang berharga. Pengalaman ini menumbuhkan keinginan mereka untuk terus melanjutkan dan memperluas keterlibatan mereka dengan Matematika. Senada dengan hal ini, NCTM (Posamentier, Germain-Williams, \& Jaye, 2013:26) menyatakan bahwa:

When students work hard to solve a difficult problem or to understand a complex idea, they experience a very special feeling of accomplishment, which in turn leads to a willingness to continue and extend their engagement with mathematics.

Dengan demikian, pengalaman siswa dalam memecahkan masalah Matematika mampu memotivasi siswa untuk terus mempelajari Matematika.

Seseorang yang dihadapkan pada suatu permasalahan perlu melakukan langkah-langkah yang dapat menuntunnya dalam pemecahan permasalahannya tersebut. Langkah-langkah pemecahan masalah Matematika menurut Polya (Bennett, Burton, \& Nelson, 2012:4) terdiri dari empat langkah, yaitu memahami masalah, membuat rencana, melaksanakan rencana, dan melihat kembali. Strategi yang bisa digunakan siswa dalam membuat rencana pemecahan suatu masalah antara lain membuat tabel, gambar atau diagram; membuat model, menemukan dan menggunakan pola; trial and error; dan menuliskan kalimat Matematika.

Dalam pembelajaran pemecahan masalah Matematika, guru memberi kesempatan kepada siswa untuk aktif memikirkan, menemukan, dan melaksanakan sendiri strategi-strategi yang membantunya dalam memecahkan masalah tersebut. Jika guru membelajarkan pemecahan masalah Matematika dengan menjelaskan prosedur atau memberi contoh pemecahan maka hal ini justru kurang baik bagi perkembangan kemampuan pemecahan masalah Matematika siswa. Hal ini sesuai dengan pendapat Walle, Karp, \& BayWilliams (2014:55) bahwa:

Teaching for problem solving -in particular modelling and expaining a strategy for how to solve the problem-can actually make students worse at solving problem and doing mathematics, not better."

Kemampuan pemecahan masalah Matematika perlu dikembangkan sejak dini karena dapat membantu siswa dalam mencari solusi atau memecahkan masalah sehari-hari di kehidupannya. Semakin sering berlatih memecahkan masalah Matematika maka semakin banyak pengalaman yang diperoleh sehingga mendorong seseorang untuk menjadi pemecah masalah yang baik. Dengan demikian, penting bagi guru untuk mengupayakan pembelajaran yang memfasilitasi siswa untuk belajar dan berlatih soal-soal pemecahan masalah Matematika.

Di samping kemampuan pemecahan masalah Matematika, sikap sosial juga penting untuk dikembangkan sejak dini. Jika sejak kecil anak-anak dibiasakan untuk menerapkan berbagai bentuk sikap sosial maka ketika dewasa anak-anak telah terbiasa untuk melakukannya. Sikap sosial penting untuk dikembangkan kare- 
na manusia tidak dapat hidup sendiri tanpa bantuan dari orang lain. Manusia akan selalu mengadakan hubungan untuk pemenuhan segala kebutuhan hidupnya. Jadi, dalam kehidupan sehari-hari baik di rumah, di sekolah, maupun di masyarakat manusia tidak akan lepas dari sikap-sikap sosial. Penerapan sikap-sikap sosial ini mampu menciptakan kehidupan yang rukun, damai, dan harmonis.

Faktor-faktor yang mempengaruhi sikap sosial terbagi menjadi dua, yaitu faktor intern dan faktor ekstern. Faktor intern yaitu faktor yang terdapat dalam pribadi manusia itu sendiri. Faktor ini berupa selectivity atau daya pilih seseorang untuk menerima dan mengolah pengaruh-pengaruh yang datang dari luar. Sedangkan faktor ekstern yaitu faktor yang terdapat di luar pribadi manusia (Abu Ahmadi, 2002:171). Pengaruh-pengaruh yang datang dari luar tidak semuanya langsung diterima karena individu melakukan seleksi atau memilih pengaruh mana yang akan diterima dan pengaruh mana yang akan ditolaknya. Daya pilih seseorang untuk menerima dan menolak pengaruh-pengaruh yang datang dari luar ini disesuaikan dengan motif dan sikap yang ada di dalam dirinya, terutama yang menjadi minat perhatiannya. Jadi, ketika seseorang telah mempunyai minat dan perhatian terhadap pengaruh dari luar, maka ia akan lebih mudah untuk menerima pengaruh tersebut. Pengaruh dari luar ini berasal dari keluarga, sekolah, masyarakat, teman sebaya/kelompok bermain, dan mass media.

Sekolah adalah lembaga pendidikan yang mempunyai peran penting dalam pengembangan pengetahuan, keterampilan, dan sikap siswa. Jadi, selain mengajarkan pengetahuan dan keterampilan, guruguru perlu menanamkan dan menerapkan berbagai bentuk sikap sosial dalam setiap aktivitas pembelajaran maupun di luar pembelajaran agar anak-anak terdorong untuk melakukannya. Hal ini sesuai dengan pendapat Berns (2010:50) bahwa:
"The school acts as an agent of society in that it is organized to perpetuate that society's knowledge, skills, customs, and beliefs." Jika dalam kehidupan sehari-hari di sekolah siswa ditanamkan berbagai bentuk sikap sosial seperti kerja sama, tolong-menolong, tanggung jawab, empati, toleransi, dan kontrol diri maka lama-kelamaan berbagai bentuk sikap sosial ini akan membudaya pada diri setiap siswa.

Berdasarkan hasil survei yang dilakukan oleh Suryadi, et al. (Narohita, 2011:148) tentang "Current situation on mathematics and science education in Bandung" yang disponsori oleh JICA, pemecahan masalah Matematika merupakan salah satu kegiatan pembelajaran Matematika yang dianggap penting baik bagi guru maupun siswa di semua tingkatan mulai dari SD sampai SMA. Meskipun demikian, kegiatan pemecahan masalah Matematika masih menjadi bagian yang paling sulit dalam Matematika, baik bagi siswa yang mempelajarinya, maupun guru yang mengajarkannya.

Berdasarkan wawancara dengan guru di SD Jarakan, sekolah ini mengalami kondisi yang sama. Guru-guru merasa kesulitan dalam membelajarkan kemampuan pemecahan masalah Matematika. Guru-guru selalu berusaha mewujudkan pembelajaran pemecahan masalah Matematika sesuai dengan prinsip-prinsip pembelajaran. Namun, dalam pelaksanaannya ada banyak keterbatasan dari segi pengetahuan, pemahaman, dan pengalaman guru serta ketersediaan sarana prasarana di sekolah. Keterbatasan ini membuat mereka kesulitan dalam memilih dan menerapkan strategi, model, metode, dan media yang tepat untuk pembelajaran pemecahan masalah Matematika sehingga proses pembelajaran yang dilaksanakan masih belum sesuai dengan harapan.

Selain hal di atas, guru-guru juga menyampaikan bahwa anak-anak pasif, kurang termotivasi dan kurang konsentrasi selama pembelajaran pemecahan masalah 
Matematika. Ketika dihadapkan pada soal-soal pemecahan masalah Matematika, siswa sering kesulitan dalam proses pemecahannya. Mereka juga mudah menyerah ketika bingung dalam memahami masalah dan menentukan cara-cara untuk memecahkan masalah tersebut. Kemampuan pemecahan masalah Matematika siswa masih rendah sehingga hasil belajar Matematika belum memuaskan.

Hal senada juga diungkapkan oleh siswa-siswa SD Jarakan. Siswa-siswa mengatakan bahwa pembelajaran pemecahan masalah Matematika yang diberikan guru kurang menarik, sulit, dan membosankan. Mereka menjadi kurang bersemangat dalam belajar dan kurang memperhatikan penjelasan guru. Akibatnya, siswa sering mengalami kesulitan dalam memecahkan masalah Matematika. Siswa sering bingung dalam memahami masalah dan menentukan cara-cara penyelesaian suatu masalah Matematika. Kalau sudah begitu mereka akan menjawab seadanya saja bahkan tidak menuliskan jawaban sama sekali.

Sekarang ini, bangsa Indonesia menghadapi krisis sosial karena banyak warga masyarakat yang kurang menerapkan berbagai bentuk sikap sosial dalam kehidupan sehari-hari. Berbagai bentuk krisis sosial antara lain adalah kurang disiplin, kurang empati, kurang bertanggung jawab, kurang toleransi, kurang efektif berkomunikasi, dan kurang kontrol diri. Berbagai krisis sosial dapat terjadi akibat kurangnya perhatian, kasih sayang, pengarahan, dan pengawasan orang tua terhadap sikap dan perilaku anak serta pengaruh yang tidak baik yang berasal dari lingkungan keluarga itu sendiri, lingkungan masyarakat, kelompok bermain, dan berbagai mass media. Oleh sebab itu; perlu peran dan tanggung jawab dari para orang tua, guru, dan masyarakat sekitar untuk bersamasama menanamkan dan membiasakan berbagai bentuk sikap sosial kepada anak sejak dini.
Berdasarkan observasi di SD Jarakan, terlihat bahwa sikap sosial siswa masih kurang. Dalam pembelajaran, banyak siswa yang suka bekerja sendiri, mudah putus asa dalam belajar, rendah diri, cenderung tertutup, kurang percaya diri, tidak berbagi ilmu, dan tidak membantu temannya yang kesulitan dalam mengerjakan tugas. Di luar pembelajaran, masih dijumpai adanya siswa yang mengejek teman, memilih-milih teman, marah pada teman, menyendiri, kurang empati, dan kurang toleransi. Mengingat SD Jarakan adalah sekolah dengan rombongan belajar yang cukup banyak dan dengan siswa yang sangat heterogen (dalam hal agama, suku, budaya, kemampuan ekonomi, jenis kelamin, dan kemampuan akademik), maka sikap-sikap sosial perlu ditanamkan dan dibudayakan kepada semua siswa.

Penerapan model collaborative learning membantu siswa dalam meningkatkan penguasaan pengetahuan dan keterampilan, meningkatkan pemahaman dan kemampuan pemecahan masalah, melatih siswa dalam berinteraksi sosial, dan mengembangkan berbagai sikap sosial. Collaborative learning merupakan model pembelajaran yang melibatkan partisipasi aktif dari empat siswa (dua siswa lakilaki dan dua siswa perempuan) dengan kemampuan beragam yang tergabung dalam kelompok untuk saling bertukar ide dan saling belajar membangun makna dan meningkatkan pemahaman dalam pemecahan suatu masalah atau penyelesaian suatu tugas sehingga tidak ada siswa yang melejit sendiri ataupun yang tertinggal. Kryza, Duncan, \& Stephens (2009:31) mengatakan bahwa:

Collaborative learning is when students work effectively together o project or taks. The brain ia a social brain dan learns more effectively in a learning community than in isolation (two heads are bettter than one).

Dengan demikian, belajar dengan teman akan lebih efektif daripada belajar 
sendiri karena siswa dapat lebih terlibat secara aktif. Sato (2013:26) mengemukakan bahwa pembelajaran kolaboratif adalah hubungan saling belajar, yaitu pembelajaran yang berangkat dari pertanyaan siswa yang tidak paham "Bagaimana mengerjakan bagian ini?", dan siswa yang paham dan yang tidak paham mendapatkan manfaat dan terjadi hubungan timbal balik. Jadi, dalam pembelajaran kolaboratif, siswa dapat saling belajar untuk meningkatkan pemahaman mereka.

Collaborative learning mengedepankan kedekatan sosial yang dapat mengembangkan pengetahuan dan pemahaman siswa. Hal ini sesuai dengan pendapat Maasaki (2012:25) bahwa collaborative learning adalah model pembelajaran dengan cara menjalin hubungan sosial yang saling punya simpati yang pada akhirnya dapat memunculkan perkembangan dan pertumbuhan intelektual siswa.

Parke \& Clarke-Stewart (2011:24) mengatakan bahwa: "Vygotsky's theory that development emerges from interactions with more skilled people and the institutions and the tools provided by culture." Jadi, teori Vygotsky mengutamakan pentingnya interaksi bagi perkembangan anak. Keyakinan Vygotsky mengenai pentingnya pengaruh sosial dalam perkembangan kognitif anak tercermin di dalam konsepnya yaitu Zone of Proximal Develoment (ZPD). "ZPD is a range of tasks that a child can carry out with the help of someone who is more skilled" (Rathus, 2014:24). Jadi, ZPD adalah serangkaian tugas yang dapat diselesaikan anak melalui bantuan orang lain yang lebih terampil. Penerapan model collaborative learning juga mengembangkan ZPD anak sehingga penguasaan anak menjadi lebih baik.

Ada beberapa syarat yang harus dipenuhi dalam penerapan model collaborative learning. Syarat-syarat itu adalah sebagai berikut: Pertama, setiap kelompok terdiri dari empat siswa (dua siswa laki-laki dan dua siswa perempuan yang saling duduk bersilang) dengan kemam- puan beragam. Ada kalanya kondisi rombongan belajar tidak memungkinkan untuk pembentukan kelompok seperti ini. Namun, sedapat mungkin dihindarkan komposisi tiga perempuan satu laki-laki dan kelompok yang anggotanya lebih dari empat orang karena kondisi demikian menyebabkan kelompok menjadi kurang efektif. Gambar komposisi kelompok ideal dalam penerapan model collaborative learning (Maasaki, 2012:78) disajikan dalam Gambar 1 berikut ini.

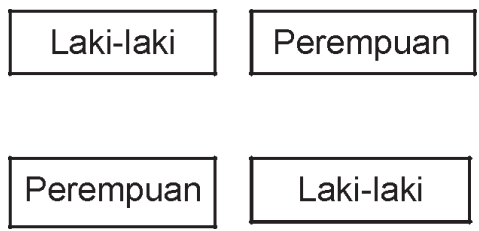

Gambar 1. Komposisi Kelompok Ideal dalam Colllaborative Learning

Kedua, menerapkan langkah-langkah pembelajaran yang terdiri dari: 1) Mengorientasikan siswa; 2) Membentuk kelompok; 3) Menyusun tugas pembelajaran; 4) Memfasilitasi kolaborasi siswa, dan 5) Memberi nilai dan mengevaluasi pembelajaran kolaboratif (Barkley, Cross, \& Major, 2012:44). Ketiga, terdapat tata cara pembelajaran yang terdiri dari 3 aturan yaitu: 1) Siswa yang belum memahami cara penyelesaian soal, jangan malu, tetapi harus bertanya kepada kawannya; 2) Siswa yang ditanya, harus menjelaskan pemikirannya secara terbuka, dan berulang kali menjelaskan cara penyelesaiannya sampai kawan tersebut benar-benar memahami; dan 3) Tidak boleh seorang siswa yang sudah menyelesaikan soal menawarkan untuk mengajar kepada siswa yang belum menyelesaikan soalnya (Masaaki, 2012:29). Tata cara pembelajaran ini harus disampaikan setelah pembentukan kelompok agar pembelajaran sesuai dengan yang diharapkan.

Keempat, adanya hubungan saling menghargai perbedaan pendapat dan tanggapan yang lembut ketika ada siswa 
yang meminta bantuan (Maasaki, 2012:28). Dalam kegiatan saling bertukar ide, sering terjadi perbedaan pendapat antarsiswa. Oleh sebab itu, siswa harus selalu menghargai setiap pendapat yang berbeda. Dalam kegiatan saling belajar, siswa yang kurang paham dapat bertanya kepada siswa yang lebih paham. Ketika siswa yang lebih paham dimintai bantuan oleh temannya yang kurang paham maka ia harus membantu menjelaskan dengan perasaan senang, sabar, dan penuh ketulusan.

Kelima, guru berada di posisi yang dapat memandangi seluruh ruang kelas sehingga dapat menemukan siswa yang bingung, terasing dari siswa lain, atau kelompok yang kurang aktif, dan dengan segera memberikan bantuan pada mereka (Maasaki, 2012:81). Jadi, guru memotivasi siswa agar selalu aktif untuk saling bertukar ide dan saling belajar dalam kelompok.

Keenam, meski dilaksanakan dalam kelompok, pembelajaran bukan untuk mencapai kesatuan melalui kegiatan kelompok. Para siswa dalam kelompok didorong untuk menemukan beragam pendapat atau pemikiran yang dikeluarkan oleh tiap individu dalam kelompok (Djamilah Bondan Widjadjanti, 2008:3). Dengan demikian, guru tidak boleh berusaha menyatukan pendapat dan ide para siswa dalam kelompok. Guru juga tidak boleh meminta mereka untuk menyatakan pendapat mereka sebagai perwakilan pendapat dari kelompok. Jadi, siswa yang maju untuk presentasi bukan merupakan perwakilan kelompok yang menyampaikan hasil pendapat kelompoknya.

Ketujuh, dalam kelompok tidak terdapat ketua kelompok dan tidak ada kompetisi antarsiswa atau antarkelompok. Tidak adanya kompetisi membuat siswa lebih terbuka sehingga tidak enggan untuk saling berbagai ilmu.

Model collaborative learning memiliki beberapa keunggulan, yaitu: 1) Merupakan esensi pembelajaran, 2) Mewujudkan hak belajar setiap siswa, 3) Merupakan sarana memperbaiki kemampuan akademis siswa yang rendah, dan 4) Menjamin siswa dengan kemampuan akademis tinggi untuk lebih baik (Sato, 2013:21). Collaborative learning merupakan esensi pembelajaran karena pada dasarnya pembelajaran membutuhkan guru dan teman sebaya untuk berkolaborasi. Collaborative learning dapat mewujudkan hak belajar setiap siswa karena belajar kelompok menjadi sarana yang paling kuat untuk menstimulasi pembelajaran. Collaborative learning merupakan sarana memperbaiki kemampuan akdemis siswa yang rendah dan menjamin siswa dengan kemampuan akademis tinggi untuk lebih baik lagi karena melalui kegiatan saling belajar, siswa dengan kemampuan akademis rendah dan tinggi sama-sama memperoleh keuntungan yang membantu mereka menjadi lebih berkembang. Dalam collaborative learning, pemahaman siswa dengan kemampuan akademis tinggi juga lebih baik karena adanya materi jumping. Materi jumping mencakup penambahan, pengaplikasian, perluasan, atau pendalaman terhadap materi yang telah dipelajari.

Collaborative learning memberikan manfaat bagi siswa karena dapat mengembangkan berbagai keterampilan, yaitu: 1) Cognitive skills such as the ability to analyze, evaluate and synthesize information; 2) Critical thinking and problem-solving skils; 3) Numeracy, literacy and visual communication skills; 4) Skills in interpersonal understanding, with the capacity to communicate effectively and to work both independently and cooperatively; dan 5) A commitment to continuous learning ('Ayon, 2013:65). Berbagai keterampilan ini penting dalam pembelajaran di sekolah dan kelak menjadi bekal siswa dalam mempersiapkan diri menuju dunia kerja.

Penelitian ini bertujuan untuk: 1) Mendeskripsikan pengaruh model collaborative learning terhadap kemampuan pemecahan masalah Matematika siswa kelas V SD Jarakan, 2) Mendeskripsikan pengaruh 
model collaborative learning terhadap sikap sosial siswa kelas V SD Jarakan, dan 3) Mendeskripsikan pengaruh model collaborative learning terhadap kemampuan pemecahan masalah Matematika dan sikap sosial siswa kelas V SD Jarakan.

\section{METODE PENELITIAN}

Jenis penelitian ini adalah penelitian eksperimen semu (quasi experiment). Penelitian ini dilakukan di SD Jarakan yang terletak di Dusun Kweni, Kelurahan Panggungharjo, Kecamatan Sewon, Kabupaten Bantul. Penelitian dilaksanakan pada bulan November-Desember 2014.

Populasi dalam penelitian ini adalah seluruh kelas V SD Jarakan pada tahun ajaran 2014/2015 yang terdiri dari empat kelas yaitu kelas 5a, 5b,5c, dan 5d. Sampel sejumlah tiga kelas ditentukan melalui pengundian. Berdasarkan hasil pengundian ditentukan bahwa kelas $5 \mathrm{c}$ dan $5 \mathrm{~d}$ sebagai kelompok eksperimen sedangkan kelas 5b sebagai kelompok kontrol.

Penelitian ini menggunakan desain randomized pretest-posttest control group design. Pretes dan angket awal diberikan kepada ketiga kelompok untuk mengukur kemampuan pemecahan masalah Matematika dan sikap sosial siswa sebelum pembelajaran. Sesudah diberikan pretes dan angket awal, kedua kelompok eksperimen melakukan pembelajaran menggunakan model collaborative learning, sedangkan kelompok kontrol melakukan pembelajaran menggunakan model ekspositori yang sudah biasa diterapkan dalam pembelajaran sehari-hari. Setelah selesai pembelajaran, ketiga kelompok diberikan postes dan angket akhir untuk mengukur kemampuan pemecahan masalah Matematika dan sikap sosial siswa setelah pembelajaran.

Data yang diperoleh dari penelitian ini secara umum dapat dibedakan menjadi dua, yaitu data tentang kemampuan pemecahan masalah Matematika siswa dan data tentang sikap sosial siswa. Data tentang kemampuan pemecahan masalah Matematika dikumpulkan melalui tes, sedangkan data tentang sikap sosial siswa dikumpulkan melalui angket. Tes yang digunakan berupa enam butir soal uraian sedangkan angket yang digunakan berupa daftar cocok (checklist) yang memuat pernyataan-pernyataan sikap sosial. Tes dan angket diberikan sebelum dan sesudah pembelajaran.

Data tentang kemampuan pemecahan masalah Matematika siswa dan data tentang sikap sosial siswa dianalisis menggunakan analisis deskriptif dan analisis inferensial. Analisis deskriptif digunakan untuk menggambarkan kondisi kemampuan pemecahan masalah Matematika dan sikap sosial siswa ketiga kelompok sebelum dan sesudah pembelajaran, sedangkan analisis inferensial digunakan untuk menguji hipotesis penelitian.

Analisis deskriptif disajikan dalam bentuk tabel (mean, median, modus, nilai tertinggi, dan nilai terendah). Skor yang diperoleh dari pretes dan postes kemampuan pemecahan masalah Matematika siswa dikonversi menjadi nilai dengan rentang 0 sampai dengan 100 dan dikelompokkan menggunakan kriteria pada Tabel 1 berikut.

Tabel 1. Kriteria Kemampuan Pemecahan Masalah Matematika Siswa

\begin{tabular}{cc}
\hline Nilai $(X)$ & Kriteria \\
\hline $80 \leq X \leq 100$ & Sangat Tinggi (ST) \\
$65 \leq X \leq 79,99$ & Tinggi (T) \\
$55 \leq X \leq 64,99$ & Sedang (S) \\
$40 \leq X \leq 54,99$ & Rendah (R) \\
$0 \leq X \leq 39,99$ & Sangat Rendah (SR) \\
\hline
\end{tabular}

Penilaian angket sikap sosial menggunakan model skala likert dengan kriteria: Selalu (S), Sering (SR), Kadang-kadang $(\mathrm{KK})$, Jarang (JR), dan Tidak Pernah (TP). Pedoman penskorannya disajikan dalam Tabel 2. 
Tabel 2. Pedoman Penskoran Angket Sikap Sosial

\begin{tabular}{cccc}
\hline $\begin{array}{c}\text { Pernyataan } \\
\text { Positif }\end{array}$ & Skor & $\begin{array}{c}\text { Pernyataan } \\
\text { Negatif }\end{array}$ & Skor \\
\hline S & 5 & S & 1 \\
SR & 4 & SR & 2 \\
KK & 3 & KK & 3 \\
JR & 2 & JR & 4 \\
TP & 1 & TP & 5 \\
\hline
\end{tabular}

Skor yang diperoleh dari angket awal dan angket akhir kemudian dikelompokkan berdasarkan kriteria yang diadopsi dari Syaifuddin Azwar (2011:163) berikut ini.

Tabel 3. Kriteria Sikap Sosial Siswa

\begin{tabular}{ccc}
\hline Interval & Skor & Kriteria \\
\hline $\mathrm{Mi}+1,5 \mathrm{SDi}<$ & $160<\leq$ & Sangat Baik \\
$\leq \mathrm{Mi}+3 \mathrm{Sdi}$ & 200 & (SB) \\
$\mathrm{Mi}+0,5 \mathrm{Sdi}<$ & $133,34<$ & Baik (B) \\
$\leq \mathrm{Mi}+1,5 \mathrm{SDi}$ & $\leq 160$ & \\
$\mathrm{Mi}-0,5 \mathrm{SDi}<$ & $106,67<$ & Cukup (C) \\
$\leq \mathrm{Mi}+0,5 \mathrm{SDi}$ & $\leq 133,34$ & \\
$\mathrm{Mi}-1,5 \mathrm{SDi}<$ & $80<$ & Kurang (K) \\
$\leq \mathrm{Mi}-0,5 \mathrm{Di}$ & $\leq 106,67$ & \\
$\mathrm{Mi}-3 \mathrm{SDi}<$ & $40<\leq$ & Sangat \\
$\leq \mathrm{Mi}-1,5 \mathrm{SDi}$ & 80 & kurang (SK) \\
\hline Skor maksimal & $=200$ & \\
$\mathrm{Skor}$ minimal & $=40$ & \\
$\mathrm{Mi}=(40+200) / 2$ & $=120$ & \\
$\mathrm{SDi}=(200-40) / 6$ & $=26,67$ &
\end{tabular}

Pengujian hipotesis dalam penelitian ini menggunakan uji $t$ independen (independent-samples t-test) dan MANOVA (multivariate analysis ofvariance). Uji t digunakan utuk melihat pengaruh model collaborative learning terhadap kemampuan pemecahan masalah Matematika dan pengaruh model collaborative learning terhadap sikap sosial siswa. MANOVA digunakan untuk melihat pengaruh model collaborative learning terhadap kemampuan pemecahan masalah Matematika dan sikap sosial siswa secara bersama-sama. Perhitungan MANOVA mengunakan uji multivariat statistik $T^{2}$ Hotelling's. Uji t dan uji $T^{2}$ Hotelling's dilakukan dengan menggunakan bantuan program SPSS 17. 0 for windows. Hipotesis yang diujikan yaitu:

Hipotesis pertama

$H_{01}: \mu_{k c l} \leq \mu_{k e}:$ Tidak terdapat pengaruh positif dan signifikan penggunaan model collaborative learning terhadap kemampuan pemecahan masalah Matematika siswa.

$H_{a 1}: \mu_{k c l}>\mu_{k e}$ : Terdapat pengaruh positif dan signifikan penggunaan model collaborative learning terhadap kemampuan pemecahan masalah Matematika siswa.

Di mana $\mu_{k c l}$ menyatakan mean (rerata) kemampuan pemecahan masalah Matematika siswa menggunakan model collaborative learning, sedangkan $\mu_{k e}$ menyatakan mean (rerata) kemampuan pemecahan masalah Matematika siswa menggunakan model ekspositori.

Hipotesis kedua

$H_{02}: \mu_{s c l} \leq \mu_{s e}:$ Tidak terdapat pengaruh positif dan signifikan penggunaan model collaborative learning terhadap sikap sosial siswa.

$H_{a 2}: \mu_{s c l}>\mu_{s e}:$ Terdapat pengaruh positif dan signifikan penggunaan model collaborative learning terhadap sikap sosial siswa.

Di mana $\mu_{\text {scl }}$ menyatakan mean (rerata) sikap sosial siswa menggunakan model collaborative learning, sedangkan $\mu_{\text {se }}$ menyatakan mean (rerata) sikap sosial siswa menggunakan model ekspositori.

Pengujian hipotesis pertama dan kedua menggunakan analisis uji $\mathrm{t}$ dengan kriteria: jika signifikansi yang dihasilkan lebih kecil dari 0,05 maka $H_{02}$ ditolak.

Hipotesis ketiga $H_{03}:\left(\begin{array}{l}\mu_{k c l} \\ \mu_{s c l}\end{array}\right)=\left(\begin{array}{l}\mu_{k e} \\ \mu_{s e}\end{array}\right): \begin{aligned} & \text { Tidak terdapat pengaruh } \\ & \text { positif dan signifikan }\end{aligned}$ 


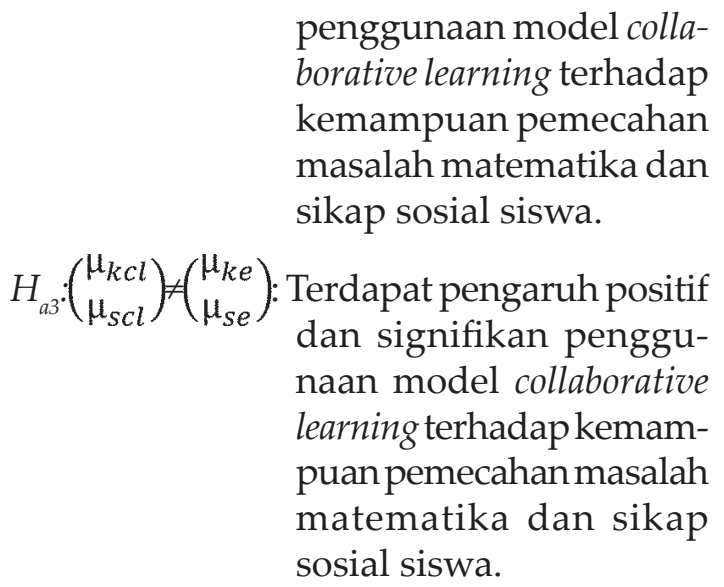

Pengujian hipotesis ketiga menggunakan analisis multivariat statistik $T^{2}$ Hotelling's dengan kriteria: jika signifikansi yang dihasilkan lebih kecil dari 0,05 maka $H_{03}$ ditolak.

\section{HASIL DAN PEMBAHASAN}

Hasil Penelitian

Kemampuan Pemecahan Masalah Matematika

Hasil penelitian berupa data tentang kemampuan pemecahan masalah Matematika dibedakan menjadi dua, yaitu data pretes dan data postes. Data pretes kemampuan pemecahan masalah Matematika siswa pada kelompok eksperimen 1, kelompok eksperimen 2, dan kelompok kontrol disajikan pada Tabel 4.

Tabel 4. DataPretesKemampuanPemecahan Masalah Matematika Siswa

\begin{tabular}{lccc}
\hline Deskripsi & KE1 & KE 2 & KK \\
\hline Mean & 60,10 & 59,98 & 60,21 \\
Median & 60,27 & 61,64 & 58,90 \\
Modus & 60,27 & 56,16 & 58,90 \\
Nilai tertinggi & 87,67 & 86,30 & 83,56 \\
Nilai terendah & 26,03 & 30,14 & 24,66 \\
\hline
\end{tabular}

Sedangkan data postes kemampuan pemecahan masalah Matematika disajikan pada Tabel 5.
Tabel 5. DataPostesKemampuanPemecahan Masalah Matematika Siswa

\begin{tabular}{lrrr}
\hline Deskripsi & \multicolumn{1}{c}{ KE1 } & \multicolumn{1}{c}{ KE 2 } & \multicolumn{1}{c}{ KK } \\
\hline Mean & 82,25 & 82,73 & 74,56 \\
Median & 83,56 & 84,93 & 73,97 \\
Modus & 83,56 & 84,93 & 71,23 \\
Nilai tertinggi & 98,3 & 100,00 & 94,52 \\
Nilai terendah & 58,90 & 63,01 & 47,95 \\
\hline
\end{tabular}

Tabel 4 dan Tabel 5 menunjukkan bahwa semua kelompok mengalami peningkatan nilai rata-rata kemampuan pemecahan masalah Matematika setelah diberikan perlakuan. Kelompok eksperimen 1 mengalami peningkatan nilai rata-rata sebesar 22,15; kelompok eksperimen 2 mengalami peningkatan nilai rata-rata sebesar 22,75; dan kelompok kontrol mengalami peningkatan nilai rata-rata sebesar 14,35. Dengan demikian, kelompok eksperimen 1 dan kelompok ekperimen 2 yang menggunakan model collaborative learning mengalami peningkatan nilai rata-rata kemampuan pemecahan masalah Matematika yang lebih besar daripada kelompok kontrol yang menggunakan model ekspositori. Peningkatan nilai rata-rata kemampuan pemecahan masalah Matematika siswa ketiga kelompok terlihat pada Gambar 2.

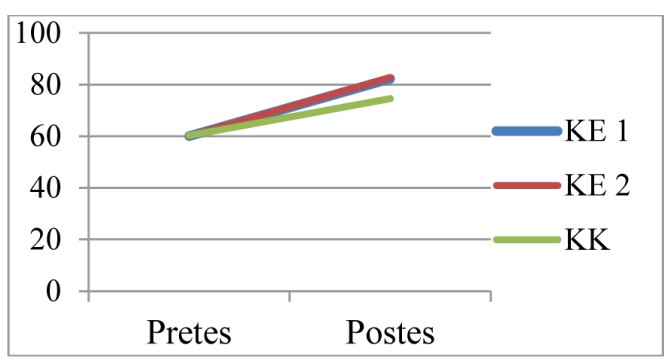

Gambar 2. Peningkatan Kemampuan

Pemecahan Masalah Matematika Siswa

Hasil pretes dan postes digunakan untuk mengelompokkan siswa dalam kategori berkemampuan sangat tinggi, tinggi, sedang, rendah, dan sangat rendah. Perbandingan persentase siswa yang memenuhi kriteria berkemampuan sangat tinggi, tinggi, sedang, rendah, dan sangat 
rendah pada kelompok eksperimen 1, kelompok eksperimen 2, dan kelompok kontrol berdasarkan hasil pretes dapat dilihat pada Tabel 6 .

Tabel 6. Distribusi Frekuensi Hasil Pretes

\begin{tabular}{lcccccc}
\hline \multirow{2}{*}{ Kriteria } & \multicolumn{2}{c}{ KE 1} & \multicolumn{3}{c}{ KE 2} & \multicolumn{1}{l}{ KK } \\
\cline { 2 - 7 } & f & $\%$ & f & $\%$ & f & $\%$ \\
\hline Sangat Tinggi & 1 & 4 & 2 & 9 & 2 & 10 \\
Tinggi & 9 & 39 & 7 & 30 & 6 & 28 \\
Sedang & 5 & 22 & 7 & 30 & 6 & 28 \\
Rendah & 6 & 26 & 5 & 22 & 5 & 24 \\
Sangat Rendah & 2 & 9 & 2 & 9 & 2 & 10 \\
\hline
\end{tabular}

Jika dibuat grafik, maka grafiknya disajikan pada Gambar 3.

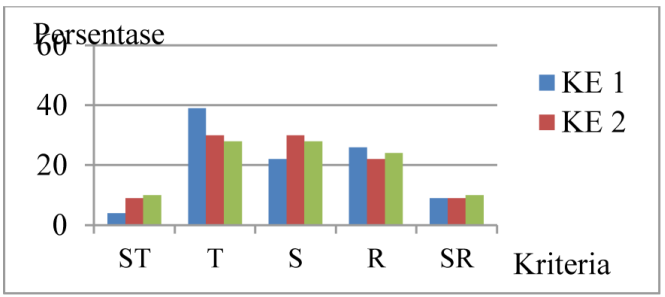

Gambar 3. Persentase Pretes

Kemampuan Pemecahan Masalah Matematika Siswa

Perbandingan persentase siswa yang memenuhi kriteria berkemampuan sangat tinggi, tinggi, sedang, rendah, dan sangat rendah pada kelompok eksperimen 1 , kelompok eksperimen 2, dan kelompok kontrol berdasarkan hasil postes dapat dilihat pada Tabel 7.

Tabel 7. Distribusi Frekuensi Hasil Postes

\begin{tabular}{lcccccc}
\hline \multirow{2}{*}{ Kriteria } & \multicolumn{3}{c}{ KE 1} & \multicolumn{2}{c}{ KE 2} & \multicolumn{2}{c}{ KK } \\
\cline { 2 - 7 } & f & $\%$ & f & $\%$ & f & $\%$ \\
\hline Sangat Tinggi & 15 & 65 & 15 & 65 & 8 & 38 \\
Tinggi & 6 & 26 & 6 & 26 & 11 & 52 \\
Sedang & 2 & 9 & 2 & 9 & 0 & 0 \\
Rendah & 0 & 0 & 0 & 0 & 2 & 10 \\
Sangat Rendah & 0 & 0 & 0 & 0 & 0 & 0 \\
\hline
\end{tabular}

Jika dibuat grafik, maka grafiknya ada pada Gambar 4.

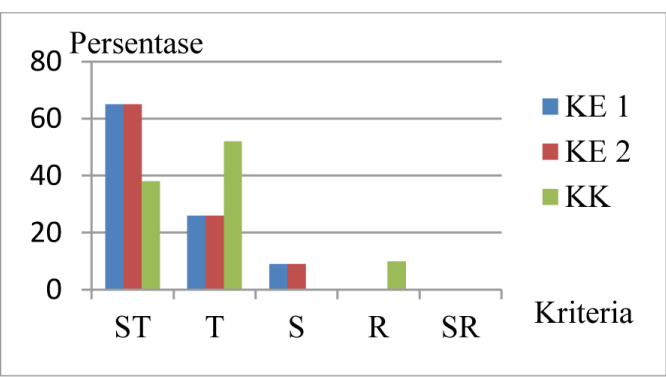

Gambar 4. Persentase Postes Kemampuan Pemecahan Masalah Matematika Siswa

Gambar 3 dan Gambar 4 menunjukkan bahwa kelompok eksperimen 1 dan kelompok eksperimen 2 yang menggunakan model collaborative learning mengalami peningkatan persentase siswa berkemampuan sangat tinggi yang lebih besar daripada kelompok kontrol yang menggunakan model ekspositori.

\section{Sikap Sosial}

Hasil penelitian berupa data sikap sosial siswa dibedakan menjadi dua, yaitu data sikap sosial awal dan data sikap sosial akhir. Data sikap sosial awal diperoleh dari angket awal sedangkan data sikap sosial akhir diperoleh dari angket akhir. Data sikap sosial awal siswa disajikan dalam Tabel 8.

Tabel 8. Data Sikap Sosial Awal Siswa

\begin{tabular}{lccc}
\hline Deskripsi & KE1 & KE 2 & KK \\
\hline Mean & 133,3 & 135,48 & 133,38 \\
Median & 133 & 133 & 133 \\
Modus & 125 & 132 & 127 \\
Skor tertinggi & 167 & 164 & 167 \\
Skor terendah & 98 & 104 & 95 \\
\hline
\end{tabular}

Sedangkan data sikap sosial akhir siswa disajikan pada Tabel 9. 
Tabel 9. Data Sikap Sosial Akhir Siswa

\begin{tabular}{lccc}
\hline Deskripsi & KE1 & KE 2 & KK \\
\hline Mean & 162,2 & 164,4 & 146,3 \\
Median & 162 & 167 & 140 \\
Modus & 162 & 168 & 140 \\
Skor tertinggi & 188 & 187 & 182 \\
Skor terendah & 137 & 142 & 120 \\
\hline
\end{tabular}

Tabel 8 dan Tabel 9 menunjukkan bahwa semua kelompok mengalami peningkatan skor rata-rata sikap sosial siswa setelah diberikan perlakuan. Kelompok eksperimen 1 mengalami peningkatan skor rata-rata sebesar 28,9; kelompok eksperimen 2 mengalami peningkatan skor ratarata sebesar 28,92; dan kelompok kontrol mengalami peningkatan skor rata-rata sebesar 12,92. Dengan demikian, kelompok eksperimen 1 dan kelompok ekperimen 2 yang menggunakan model collaborative learning mengalami peningkatan skor ratarata sikap sosial yang lebih besar daripada kelompok kontrol yang menggunakan model ekspositori. Peningkatan skor ratarata sikap sosial siswa ketiga kelompok terlihat pada Gambar 5.

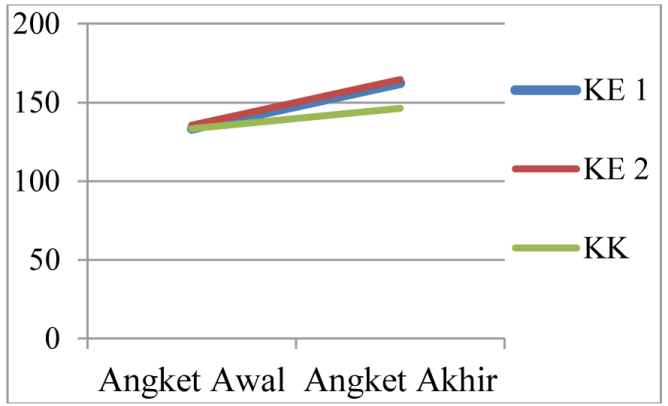

Gambar 5. Peningkatan Sikap Sosial Siswa

Hasil angket awal dan angket akhir sikap sosial siswa digunakan untuk mengelompokkan siswa dalam kategori bersikap sosial sangat baik, baik, cukup, kurang, dan sangat kurang. Perbandingan persentase siswa bersikap sosial awal sa- ngat baik, baik, cukup, kurang, dan sangat kurang pada kelompok eksperimen 1, kelompok eksperimen 2, dan kelompok kontrol disajikan pada Tabel 10 berikut.

Tabel 10. Distribusi Frekuensi Sikap Sosial Awal Siswa

\begin{tabular}{lcccccc}
\hline \multirow{2}{*}{ Kriteria } & \multicolumn{2}{c}{ KE 1 } & \multicolumn{2}{c}{ KE 2} & & KK \\
\cline { 2 - 7 } & f & $\%$ & f & $\%$ & f & $\%$ \\
\hline Sangat Baik & 2 & 9 & 1 & 4 & 2 & 9,5 \\
Baik & 9 & 39 & 11 & 48 & 8 & 38 \\
Cukup & 11 & 48 & 9 & 39 & 9 & 43 \\
Kurang & 1 & 4 & 2 & 9 & 2 & 9,5 \\
Sangat Kurang & 0 & 0 & 0 & 0 & 0 & 0 \\
\hline
\end{tabular}

Jika dibuat grafik, maka grafiknya ada pada Gambar 6 berikut ini.

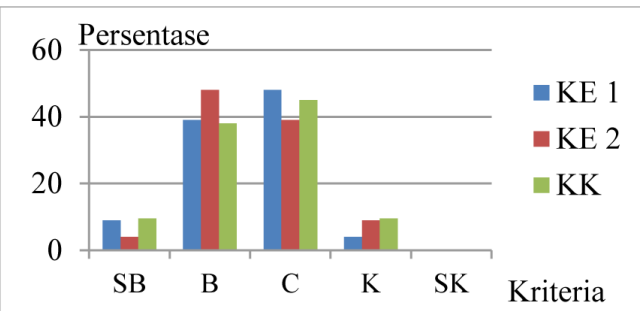

Gambar 6. Persentase Sikap Sosial Awal Siswa

Perbandingan persentase siswa bersikap sosial akhir sangat baik, baik, cukup, kurang, dan sangat kurang pada kelompok eksperimen 1, kelompok eksperimen 2, dan kelompok kontrol dapat dilihat pada Tabel 11.

Tabel 11. Distribusi Frekuensi Sikap Sosial Akhir Siswa

\begin{tabular}{lcccccc}
\hline & \multicolumn{2}{c}{ KE 1 } & \multicolumn{2}{c}{ KE 2 } & \multicolumn{2}{c}{ KK } \\
\cline { 2 - 7 } Kriteria & f & $\%$ & f & $\%$ & f & $\%$ \\
\hline Sangat Baik & 14 & 61 & 12 & 52 & 5 & 24 \\
Baik & 9 & 39 & 11 & 48 & 10 & 48 \\
Cukup & 0 & 0 & 0 & 0 & 6 & 28 \\
Kurang & 0 & 0 & 0 & 0 & 0 & 0 \\
Sangat Kurang & 0 & 0 & 0 & 0 & 0 & 0 \\
\hline
\end{tabular}


Jika dibuat grafik, maka grafiknya ada pada Gambar 7.

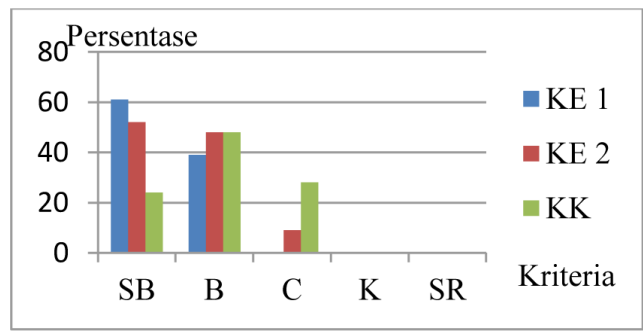

Gambar 7. Persentase Postes Kemampuan

Pemecahan Masalah Matematika Siswa

Gambar 6 dan Gambar 7 menunjukkan bahwa kelompok eksperimen 1 dan kelompok eksperimen 2 yang menggunakan model collaborative learning mengalami peningkatan persentase siswa bersikap sosial sangat baik yang lebih besar daripada kelompok kontrol yang menggunakan model ekspositori.

\section{Hasil Uji Hipotesis}

Data yang digunakan dalam pengujian hipotesis adalah data hasil postes kemampuan pemecahan masalah Matematika dan hasil angket akhir sikap sosial siswa pada kelompok eksperimen 1, kelompok eksperimen 2, dan kelompok kontrol. Namun, sebelum dilakukan pengujian hipotesis, dilakukan pengujian persyaratan analisis yang meliputi uji normalitas dan uji homogenitas terhadap data-data tersebut. Uji normalitas digunakan untuk mengetahui apakah data berdistribusi normal atau tidak. Perhitungan uji normalitas dilakukan menggunakan metode Kolmogorof Smirnov, dengan kriteria: 1) jika nilai Asym. Sig. (2-tailed) lebih besar dari 0,05 maka 0 diterima sehingga data berdistribusi normal, 2) jika nilai Asym. Sig. (2-tailed) lebih kecil dari 0,05 maka 0 ditolak sehingga data tidak berdistribusi normal. Uji normalitas dilakukan dengan menggunakan bantuan SPSS 17.0. for windows. Tabel 12 menyajikan hasil uji normalitas data hasil postes kemampuan pemecahan masalah Matematika dan data hasil angket akhir sikap sosial siswa pada kelompok eksperimen 1, kelompok eksperimen 2, dan kelompok kontrol.

Tabel 12. Hasil Uji Normalitas Data Postes dan Angket Akhir

\begin{tabular}{cccc}
\hline Kel & Data & Sig & Hasil \\
\hline KE 1 & Postes & 0,151 & Sig $>\alpha$ \\
& Angket akhir & $0,200^{*}$ & Sig $>\alpha$ \\
KE 2 & Postes & 0,189 & Sig $>\alpha$ \\
& Angket akhir & $0,200^{*}$ & Sig $>\alpha$ \\
KK & Postes & $0,200^{*}$ & Sig $>\alpha$ \\
& Angket akhir & $0,200^{*}$ & Sig $>\alpha$ \\
\hline
\end{tabular}

Tabel 12 menunjukkan bahwa hasil uji normalitas data postes kemampuan pemecahan masalah Matematika dan data angket akhir sikap sosial siswa setiap kelompok memiliki nilai signifikansi lebih besar dari nilai alpha. Karena nilai signifikansinya lebih besar dari nilai alpha maka 0 diterima. Dengan demikian, data postes dan data angket akhir siswa setiap kelompok merupakan data yang berdistribusi normal.Uji homogenitas digunakan untuk mengetahui apakah kelompok data memiliki varians yang homogen atau tidak. Perhitungan uji homogenitas menggunakan homogenitas Levene dengan kriteria: 1) jika nilai signifikansi lebih dari 0,05 maka data memiliki varians yang homogen, 2) jika nilai signifikansi kurang dari 0,05 maka data memiliki varians yang tidak homogen. Uji homogenitas menggunakan bantuan program SPSS 17.0 for windows. Hasil uji homogenitas data hasil postes kemampuan pemecahan masalah Matematika dan data hasil angket akhir sikap sosial siswa pada ketiga kelompok disajikan pada Tabel 13.

Tabel 13. Hasil Uji Homogenitas Data Postes dan Angket Akhir

\begin{tabular}{lcccc}
\hline & $\begin{array}{c}\text { Levene } \\
\text { Statistic }\end{array}$ & df1 & df2 & Sig. \\
\hline Postes & 0,370 & 2 & 64 & 0,692 \\
Angket akhir & 2,651 & 2 & 64 & 0,078 \\
\hline
\end{tabular}


Tabel 13 menunjukkan bahwa hasil uji homogenitas data postes kemampuan pemecahan masalah Matematika dan data angket akhir sikap sosial siswa ketiga kelompok memiliki nilai signifikansi yang lebih besar daripada nilai alpha $(0,05)$. Karena nilai signifikansinya lebih besar dari 0,05 maka data-data tersebut memiliki varians yang homogen. Setelah diketahui bahwa data hasil postes kemampuan pemecahan masalah Matematika dan data hasil angket akhir sikap sosial siswa berdistribusi normal dan memiliki varians yang homogen, maka dilakukan pengujian terhadap masing-masing hipotesis.

Pada pengujian hipotesis pertama, hasil uji $t$ data postes kemampuan pemecahan masalah Matematika antara siswa kelompok eksperimen (kelompok eksperimen 1 dan 2 digabung) dan kelompok kontrol disajikan pada Tabel 14.

Tabel 14. Hasil Uji t Data Postes Kemampuan Pemecahan Masalah Matematika

\begin{tabular}{ccccc}
\hline & $\mathrm{t}$ & $\mathrm{df}$ & Sig. & Perbedaan mean \\
\hline Nilai & 2,741 & 65 & 0,008 & 7,92973 \\
\hline
\end{tabular}

Tabel 14 menunjukkan bahwa hasil uji t data postes kemampuan pemecahan masalah Matematika siswa kelompok eksperimen dan kelompok kontrol memiliki nilai signifikansi lebih kecil dari 0,05. Karena nilai signifikansinya lebih kecil dari 0,05 maka 01 ditolak. Dengan demikian dapat disimpulkan bahwa terdapat pengaruh positif dan signifikan penggunaan model collaborative learning terhadap kemampuan pemecahan masalah Matematika siswa.

Pada pengujian hipotesis kedua, hasil uji t data angket akhir sikap sosial antara siswa kelompok ekperimen (kelompok eksperimen 1 dan 2 digabung) dan kelompok kontrol disajikan pada Tabel 15.
Tabel 15. Hasil Uji t Data Angket Akhir Sikap Sosial Siswa

\begin{tabular}{ccccc}
\hline & $\mathrm{t}$ & $\mathrm{df}$ & Sig. & Perbedaan mean \\
\hline Nilai & 4,016 & 65 & 0,000 & 8,02019 \\
\hline
\end{tabular}

Tabel 15 menunjukkan bahwa hasil uji t data angket akhir sikap sosial siswa kelompok eksperimen dan kelompok kontrol memiliki nilai signifikansi lebih kecil dari 0,05. Karena nilai signifikansinya lebih kecil dari 0,05 maka ditolak. Dengan demikian dapat disimpulkan bahwa terdapat pengaruh positif dan signifikan penggunaan model collaborative learning terhadap sikap sosial siswa.

Pada pengujian hipotesis ketiga, hasil uji multivariat data postes kemampuan pemecahan masalah Matematika dan angket akhir sikap sosial siswa kelompok eksperimen (kelompok eksperimen 1 dan 2 digabung) dan kelompok kontrol menggunakan $T^{2}$ Hotelling's disajikan pada Tabel 16.

Tabel 16. Hasil Uji² Hotelling's

\begin{tabular}{ccccc}
\hline Value & $F$ & $\begin{array}{c}\text { Hypothesis } \\
\text { df }\end{array}$ & $\begin{array}{c}\text { Error } \\
\text { df }\end{array}$ & Sig. \\
\hline 0,302 & 9,659 & 2,000 & 64,000 & 0,000 \\
\hline
\end{tabular}

Tabel 16 menunjukkan bahwa hasil uji $T^{2}$ Hotelling's data postes kemampuan pemecahan masaah Matematika dan data angket akhir sikap sosial siswa kelompok eksperimen dan kelompok kontrol memiliki nilai signifikansi lebih kecil dari 0,05. Karena nilai signifikansinya lebih kecil dari 0,05 maka 03 ditolak. Dengan demikian dapat disimpulkan bahwa terdapat pengaruh positif dan signifikan penggunaan model collaborative learning terhadap kemampuan pemecahan masalah Matematika dan sikap sosial siswa.

\section{Pembahasan}

Penerapan model collaborative learning berpengaruh terhadap peningkatan kemampuan pemecahan masalah Matema- 
tika siswa karena mampu menciptakan komunikasi interaktif antarsiswa melalui kegiatan saling bertukar ide dan saling belajar sehingga pengetahuan dan pemahaman menjadi meningkat. Hal ini sesuai dengan pendapat Gerdy (Wiersema, 2000: 1) bahwa:

Learning is enhanced when it is more like a team effort than a solo race. Good learning, like good work, is collaborative and social, not competitive and isolated. Sharing one's ideas and responding to others' improves thinking and deepens understanding.

Dengan demikian, belajar dengan teman memberikan dampak yang lebih baik daripada belajar sendiri karena dengan berkolaborasi maka pemikiran siswa menjadi luas dan mendalam serta masalahmasalah yang awalnya sulit untuk dipecahkan sendiri oleh siswa, akhirnya dapat terselesaikan berkat bantuan teman yang terampil.

Menurut teori Vygotsky, interaksi sosial membantu pemikiran dan pemahaman siswa karena pada dasarnya perkembangan dan pembelajaran terjadi di dalam konteks sosial. Kegiatan saling bertukar ide dan saling belajar dalam collaborative learning telah melibatkan siswa untuk menyusun pemikiran dan meningkatkan pemahaman mereka melalui interaksi sosial dengan teman dalam kelompok sehingga pembelajaran menjadi lebih efektif. Hal ini sesuai dengan pernyataan Katherine, Powell, \& Kalina (2009: 243) bahwa:

All of Vygotsky's research and theories are collectively involved in social constructivism and language development such as, cognitive dialogue, the zone of proximal development, social interaction, culture, and inner speech. Understanding his theories or building a classroom where interaction is prominent helps develop effective classrooms.

Penerapan model collaborative learning memberikan keuntungan secara akademik yaitu: a) CL promotes critical thinking skills, b) involves students actively in the learning process, c) classroom results are improved, dan d) models appropriate student problem solving techniques (Laal \& Ghodsi, 2011:487). Dengan demikian, model collaborative learning dapat mengembangkan keterampilan berpikir kritis siswa, meningkatkan keaktifan siswa, meningkatkan hasil belajar siswa, dan meningkatkan kemampuan pemecahan masalah Matematika siswa.

Di samping itu, penerapan model collaborative learning berpengaruh terhadap peningkatan sikap sosial siswa karena siswa menjadi pribadi yang lebih peduli, lebih supportif, lebih berkomitmen dalam menjalin hubungan persahabatan, dan memiliki kompetensi sosial dan harga diri yang lebih baik. Hal ini sesuai dengan pendapat Laal \& Ghodsi (2011:489) bahwa:

CL compared with competitive and individualistic efforts, has numerous benefits and typically results in higher achievement and greater productivity, more caring, supportive, and committed relationships; and greater, psychological health, social competence, and self esteem.

Dengan kegiatan saling bertukar ide, siswa membiasakan diri untuk mendengarkan ide dan pendapat temannya dan menghargai setiap ide dan pemikiran yang berbeda. Jadi, penerapan collaborative learning dapat mengembangkan sikap toleransi antarsiswa. Hal ini sesuai dengan pendapat 'Ayon (2013:72) bahwa: "In addition, CL is likely to help students develop job-related skills, flexibility, tolerance, problem-solving and communication skills." Dengan demikian, penerapan model collaborative learning membantu siswa dalam mengembangkan keterampilan terkait pekerjaan, fleksibilitas, toleransi, keterampilan pemecahan masalah, dan keterampilan komunikasi.

Melalui kegiatan saling belajar, sikap tanggung jawab siswa tumbuh dan berkembang. Ketika siswa berkemampuan 
akademis rendah mengalami kebingungan atau kesulitan kemudian ia mau bertanya kepada temannya yang lebih paham maka ia telah berusaha keluar dari situasi sulit dengan cara mempercayai orang lain dan meminta bantuan pada mereka. Hal ini menunjukkan tanggung jawab siswa tersebut pada dirinya sendiri untuk dapat mengatasi permasalahan yang dihadapinya. Bagi siswa yang dimintai bantuan, ketika ia mau menjelaskan kepada temannya dengan sabar dan penuh ketulusan maka itu adalah wujud tanggung jawab sosialnya. Dengan demikian, collaborative learning mampu meningkatkan sikap tanggung jawab siswa, baik tanggung jawab siswa terhadap dirinya sendiri maupun terhadap orang lain. Hal ini sesuai dengan pendapat Dooly (2008:31) bahwa: "With older or autonomous students, group collaboration may be responsibility of the students themselves."

\section{PENUTUP}

Simpulan

Berdasarkan hasil penelitian dan pembahasan dapat disimpulkan bahwa: 1) Terdapat pengaruh positif dan signifikan penggunaan model collaborative learning terhadap kemampuan pemecahan masalah Matematika siswa kelas V SD Jarakan Sewon Bantul, 2) Terdapat pengaruh positif dan signifikan penggunaan model collaborative learning terhadap sikap sosial siswa kelas V SD Jarakan Sewon Bantul, dan 3) Terdapat pengaruh positif dan signifikan penggunaan model collaborative learning terhadap kemampuan pemecahan masalah Matematika dan sikap sosial siswa kelas V SD Jarakan Sewon Bantul.

\section{Saran}

Dari kesimpulan di atas, maka model collaborative learning dapat menjadi pilihan bagi para guru untuk meningkatkan kemampuan pemecahan masalah Matematika dan sikap sosial para siswa.

\section{DAFTAR PUSTAKA}

Abu Ahmadi (2002). Psikologi Sosial. Jakarta: Rineka Cipta.

'Ayon, N. S. (2013). Collaborative learning in English for specific purposes courses: Effectiveness and students'attitudes towards it. American Academic $\mathcal{E}$ Schoolarly Research Journal, Vol.5 No. 3, 62-75p.

Barkley, E. E., Cross, K. P., \& Major, C. H. (2012). Collaborative Learning Techniques. (Terjemahan Narulita Yusron). San Francisco: Jossey- Bass. (Buku asli diterbitkan tahun 2005).

Bennett, Jr., A. B., Burton, L. J., \& Nelson, L. T. (2012). Mathematics for Elementary Teachers a Conceptual Approach. New York: McGraw-Hill.

Berns, R. M. (2010). Child, Family, School, Community Socialization and Support, Eighth edition. Belmont: Wadsworth Cengage Learning.

Djamilah Bondan Widjadjanti. (2008). Strategi Pembelajaran Kolaboratif Berbasis Masalah. Makalah disajikan dalam Seminar Nasional Matematika dan Pendidikan Matematika 2008, di Universitas Negeri Yogyakarta.

Dooly, M. (Ed). (2008). Constructing Knowledge Together: A Guidebook to Moderating Intercultural Collaboration Online. Bern: Peter Lang.

Katherine C., Powell, \& Kalina, C. J. (2009). Cognitive and social contructivism: developing tools for an effective classroom. Education; Volume 130 No. 2: 241-25p.

Kryza, K., Duncan, A., \& Stephens, S. J. (2009). Inspiring Elementary Learners. Thousand Oaks: Corwin Press.

Laal, M. \& Ghodsi, S. M. (2011). Benefits of collaborative learning. ProcediaSocial and Behavioral Sciences 31 (2012) $486-490$

Maasaki, S. (2012). Dialog dan Kolaborasi di Sekolah Pertama. (Terjemahan Okamoto Sachie). Modul PELITA. (Buku asli diterbitkan tahun 2011). 
Narohita, G. A. (2011). Penerapan strategi pembelajaran heuristik dengan metode bekerja mundur untuk meningkatkan kemampuan pemecahan masalah Matematika. Jurnal Edukasi Matematika PPPPTK Matematika. Volume 2. 144-151p.

NCTM. (2000). Principles and Standard for School Mathematics. Reston: NCTM.

Parke, R. D. \& Clarke-Stewart, A. (2011). Social Development. Hoboken: John Wiley \& Sons, Inc.

Posamentier, A. S., Germain-Williams, T. L., \& Jaye, D. (2013). What Successful Math Teachers Do, Grades 6-12, Second Edition. Thousand Oaks: Corwin.

Rathus, S. A. (2014). Childhood Adolescence. International Edition: Cengage Learning International Office
Reys, R. et al. (2012). Helping Children Learn Mathematics. Hoboken: John Willey \& Son, Inc.

Sato, M. (2013). Mereformasi Sekolah. Tokyo: International Development Center of Japan Inc.

Syaifuddin Azwar. (2011). Penyusunan Skala Psikologi. Yogyakarta: Pustaka Pelajar.

Walle, V. D, Karp, \& Bay-Williams. (2014). Elementary and Middle School Mathematics Teaching Developmentally (8'ed). Harlow: Pearson Education Limited.

Wiersema, N. (2000). How Does Collaborative Learning Actually Work in a Classroom and How Do Students React to It?. Diakses dari www.city.londonmet. ac.uk/deliberations/collab.learning/wiersema.html. tanggal 4 Januari 2015. 